\title{
Symbiotic Seed Germination and Mycorrhizae of Federally Threatened Platanthera praeclara (Orchidaceae)
}

\author{
JYOTSNA SHARMA, ${ }^{*}{ }^{1}$ LAWRENCE W. ZETTLER,${ }^{2} \mathrm{~J} . \mathrm{W}$. VAN SAMBEEK, ${ }^{3}$ \\ MARK R. ELLERSIECK ${ }^{4}$ AND CHRISTOPHER J. STARBUCK ${ }^{1}$ \\ ${ }^{1}$ Department of Horticulture, University of Missouri, Columbia 65211 \\ ${ }^{2}$ Department of Biology, The Illinois College, Jacksonville 62650 \\ ${ }^{3}$ North Central Research Station, USDA Forest Service, Columbia, Missouri 65211 \\ ${ }^{4}$ Agricultural Experiment Station Statistics, University of Missouri, Columbia 65211
}

\begin{abstract}
In vitro culture of mycotrophic leaf-bearing seedlings of federally threatened Platanthera praeclara Sheviak and Bowles, a terrestrial orchid native to the midwestern prairies, is reported for the first time. Symbiotic germination was evaluated to: (1) determine need for cold moist stratification to enhance seed germination and seedling development and (2) identify the mycobionts that support in vitro germination and development. Germination was improved by exposing seeds to both 4 - and 6-mo stratification periods; whereas seeds without stratification failed to germinate in a pilot study. Pretreatment of seeds with 6 mo of stratification combined with inoculation with mycorrhizal fungus derived from a seedling (Ceratorhiza sp., UAMH 9847) supported development of higher stage protocorms and some leaf-bearing seedlings of $P$. praeclara. Protocorms with developing leaf primordia were also obtained by coinoculation with strains of Epulorhiza and Ceratorhiza. Fungi derived from mature $P$. praeclara plants failed to promote seedling development to advanced growth stages. Results indicate that in vitro development of $P$. praeclara is best supported when stratified seeds are cultured with fungi isolated from young seedlings.
\end{abstract}

\section{INTRODUCTION}

Terrestrial orchids native to midwestern prairies are declining in number due to loss of suitable habitat, collection pressure and poaching. Populations of one such orchidfederally threatened Platanthera praeclara-have been lost from nearly $75 \%$ of all sites historically documented to support the species [U.S. Fish and Wildlife Service (USFWS), 1996]. The Western Prairie Fringed Orchid Recovery Team has identified conversion of prairie habitat to cropland as the primary threat to the continued existence of the species. Additionally, several biological threats have been identified, such as herbivory, invasive species, erratic flowering and limited pollination (USFWS, 1996). Terrestrial orchids rely on mycotrophy to derive energy throughout their life cycle (Rasmussen, 1995), and fungal colonization is especially necessary to stimulate gluconeogenesis, to mobilize reserves and to provide nutritional support to nonphotosynthetic seedlings (Smith and Read, 1997). Therefore, an additional threat for $P$. praeclara may arise if suitable fungal symbionts are absent in the natural habitat to allow seedling establishment.

Platanthera praeclara is an herbaceous perennial occurring in prairies with a diversity of vegetative communities; however, it occurs most often in association with Carex lanuginose, Calamagrostis stricta and Juncus balticus in wet-mesic sedge meadows or in transition zones between those and the Andropogon gerardii-Schizachyrium scoparium-Panicum virgatum type wet-mesic prairies (USFWS, 1996). An average-sized inflorescence has ca. 10 creamy-white

\footnotetext{
* Corresponding author: e-mail: jsharma@iastate.edu. Current address: Department of Horticulture, Iowa State University, Ames, IA 50011.
} 
large flowers which are borne on a raceme up to $11 \mathrm{~cm}$ long and $10 \mathrm{~cm}$ wide. Each flower has a thick nectar spur ranging between $30-50 \mathrm{~mm}$ in length-the longest of any north temperate Platanthera (Summers, 1996). Pollinators for this outcrossing species (Sheviak and Bowles, 1986; Catling and Catling, 1991) have rarely been documented but are thought to be long-tongued hawkmoths (Family Sphingidae). Although Pleasants and Moe (1993) studied pollinia removal in the orchid, they did not document any specific pollen vectors. Cuthrell and Rider (1993) identified Eumorpha achemon and Sphinx drupiferarum as polliniacarrying vectors at the Sheyenne National Grasslands. In Manitoba, A. R. Westwood (pers. comm.) observed Hyles gallii and Sphinx drupiferarum moths pollinating P. praeclara. Successful pollination leads to development of capsules containing thousands of dust-like seeds. Although the reproductive potential of a single plant could be large given the number of seeds produced, recruitment of new individuals is often very low (USFWS, 1996).

Bimodal pattern of population sizes occurs in Platanthera praeclara. Large populations of several thousand plants are currently restricted to the Red River Valley in the northern part of the species' range, but populations in other parts of the range vary from a few individuals to a few hundred individuals (USFWS, 1996). Loss of genetic diversity due to genetic drift and subsequent reduction in fitness of quantitative traits, such as seed viability, in smaller populations can accelerate the decline of populations of rare plants (Godt and Hamrick, 2001). However, in outcrossing species, differences in availability and efficiency of pollinators from year to year are also expected to influence the number of viable seeds. Therefore, the size of a population alone may not be an indicator of the viability of the seeds produced by its members; pollination success and environmental conditions may also influence this quantitative trait.

Recruitment of new individuals, however, is dependent not only on seed viability but on germination and early survivorship, which may well be limited by the availability of mycorrhizal associates in fragmented or disturbed prairie habitat. Loss of functioning prairie ecosystems is the foremost and continuing threat for many rare prairie plants, and consequently, efforts in prairie restoration and protection are critical for their long-term survival. However, since wild populations of Platanthera praeclara are declining, and natural recovery is expected to be time consuming, propagation from seed is an urgently needed conservation tool to maximize the chances of survival of this rare orchid. Symbiotically cultured seedlings could be transplanted into the field to accompany other restoration efforts. The Recovery Plan for $P$. praeclara calls for use of artificial propagation [objectives 4222 and 4223 as listed in the Western Prairie Fringed Orchid Recovery Plan (USFWS, 1996)], but no reliable method has yet been documented.

Cold stratification treatments have improved in vitro germination of seeds of terrestrial orchids (Stoutamire, 1974; Coke, 1990). Stoutamire (1996) suggested 2 or more months of stratification for germination of Platanthera leucophaea, an orchid species closely related to $P$. praeclara. Leaf-bearing seedlings of $P$. leucophaea developed from seeds which were stratified for $11 \mathrm{mo}$ and inoculated with Ceratorhiza isolate (Zettler et al., 2001). Bowles et al. (2002) reported high germination to Stage 2, defined as "enlargement of protocorm beyond the original seed size and development of rhizoids," in seeds stratified for 2 and 4 mo and inoculated with a Ceratorhiza strain. Stratification requirements for seeds of other terrestrial orchids can range from 3 to 9 mo (Rasmussen, 1995) and may be species-specific. Following natural dehiscence and dispersal, seeds of $P$. praeclara likely receive exposure to 4 5 mo of cold temperatures throughout its natural range and therefore, would likely benefit from cold stratification in the laboratory.

Inclusion of natural mycobionts to cultivate terrestrial orchids in vitro leads to seedlings that are highly suitable for ex vitro transplanting (Zettler and McInnis, 1992; Zelmer and 
Currah, 1997). This propagation method also allows reintroduction of symbiotically active mycobiont along with the transplanted seedlings. In comparison, survivability of asymbiotically grown seedlings on soil is reported to be minimal (Clements et al., 1986; Anderson, 1991, 1996). Consequently, terrestrial orchid conservation programs based on in vitro symbiotic propagation and reintroduction into field sites also require a collection of suitable and viable fungal strains.

Relatively little is known of mycorrhizal fungi associated with orchids native to North American prairies. Mycobionts of adult Platanthera praeclara in Canada are reported to belong to two genera, namely, Epulorhiza and Ceratorhiza, whereas protocorms obtained after in situ incubation of seeds only yielded an Epulorhiza strain (Zelmer et al., 1996). No information is available on the fungal associates of $P$. praeclara from the United States or about the efficacy of fungi in inducing in vitro germination of the species. Moreover, in vitro germination of terrestrial orchids has mostly been tested with fungi recovered from mature plants (Dixon, 1987; Takahashi et al., 2000; Zettler and McInnis, 1992; Zettler et al., 2001; Bowles et al., 2002). However, at least two studies have reported protocorm- or seedlingderived fungi to be effective in development of advanced stage seedlings of terrestrial orchids (Zettler, 1994; Zelmer and Currah, 1997). It is expected that isolates originating from young seedlings, in comparison to those recovered from adult plants, would be more suitable for in vitro germination and protocorm development of $P$. praeclara.

The objectives of this study were to: (1) evaluate symbiotic germination after 4 mo and 6 mo stratification periods to obtain advanced stage protocorms (those with a developing leaf primordium) and leaf-bearing seedlings of Platanthera praeclara and (2) identify the fungal isolates that support in vitro germination and development of $P$. praeclara seeds.

\section{Methods}

\section{SYMBIOTIC SEED GERMINATION}

Fungal isolation.-The nonphotosynthetic root-like organ (protocorm) from a strap-leaved seedling and roots of mature Platanthera praeclara, collected from field sites in Minnesota (MN) and Missouri (MO) in July 1999, were rinsed in deionized (DI) water, surface disinfested in 1:1:1 v/v/v solution of household bleach $(5.25 \% \mathrm{NaOCl})$, ethanol $(95 \%$ $\mathrm{EtOH}$ ) and sterile DI water for $1 \mathrm{~min}$ and rinsed twice in sterile DI water. The cortical layer was removed with a sterile scalpel and the inner cortex macerated in $0.5 \mathrm{ml}$ sterile DI water. Molten Modified-Melin-Norkran's agar (MMN) was added to the tissue followed by incubation at $23 \mathrm{C}$ for a few days until fungal hyphae were observed growing from pelotons released from the root cells. Tips of hyphae originating from pelotons or orchid tissue were transferred to potato dextrose agar (PDA) to obtain pure cultures of the mycobionts. Cultures were deposited at the University of Alberta Microfungus Collection and Herbarium (UAMH) for safekeeping and future use (Table 1).

Seed collection and treatment.-Seeds of Platanthera praeclara were collected from three populations in Minnesota (Bluestem, Bicentennial and Hwy 56) and two in Missouri (Helton and Little Tarkio). Given the threatened status of the species, only up to ca. $10 \%$ of full seed capsules were harvested in late August in Missouri and mid-September in Minnesota. Undehisced mature capsules were collected from randomly chosen plants when possible. Seeds were transferred to sterile glass vials and stored over desiccant at $-20 \mathrm{C}$. A portion of the seeds was later transferred to vials with sterile DI water and subjected to cold stratification in the dark at $5 \mathrm{C}$ for the appropriate time period, i.e., $4 \mathrm{mo}$ and $6 \mathrm{mo}$. 
TABLE 1.-Fungal strains isolated from Platanthera praeclara and used in symbiotic seed germination experiments. Isolates are listed in the order of decreasing age of source tissue

\begin{tabular}{|c|c|c|c|}
\hline Isolate & Genus & Source tissue & Source population \\
\hline Hel-166 (UAMH 9846)* & Epulorhiza & $\begin{array}{l}\text { Flowering plant; new } \\
\text { lateral root }\end{array}$ & Helton, MO \\
\hline Blu-61 (UAMH 9845) & Epulorhiza & $\begin{array}{l}\text { Nonflowering vegetative plant; } \\
\text { new lateral root }\end{array}$ & Bluestem, MN \\
\hline Blu-86 (UAMH 9848) & Ceratorhiza & $\begin{array}{l}\text { Nonflowering vegetative plant; } \\
\text { new lateral root }\end{array}$ & Bluestem, MN \\
\hline Ler-94 (UAMH 9849) & Ceratorhiza & $\begin{array}{l}\text { Nonflowering vegetative plant; old } \\
\text { lateral root }\end{array}$ & Hwy 56, MN \\
\hline Bic-68 (UAMH 9844) & Epulorhiza & Strap-leaved seedling; protocorm & Bicentennial, MN \\
\hline Bic-70 (UAMH 9847) & Ceratorhiza & Strap-leaved seedling; protocorm & Bicentennial, MN \\
\hline
\end{tabular}

* Cultures were deposited at the University of Alberta Microfungus Collection and Herbarium (UAMH)

Nonstratified seeds failed to germinate in a pilot study and, therefore, a control for stratification treatment was not included in the experiment reported herein.

Seed germination.-At the end of each stratification period, seeds were sown and inoculated with appropriate fungal isolates based on procedures originally described by Dixon (1987). Briefly, seeds were surface-disinfested in a solution containing $5 \%$ ethanol, $10 \%$ household bleach and $85 \%$ sterile DI water. Following surface sterilization, 25-35 seeds were placed in a Petri plate containing modified oatmeal agar (OMA; $2.5 \mathrm{~g} \mathrm{~L}^{-1}$ ground oats, $7.0 \mathrm{~g} \mathrm{~L}^{-1}$ agar). The plates were wrapped with parafilm, covered with aluminium foil and incubated at $23 \mathrm{C}$ for the first $60 \mathrm{~d}$. Some adjustments made to the method described by Dixon (1987) included use of nylon plankton mesh (instead of filter paper strips) for placement of seeds on the sowing medium. Filter paper strips containing cellulose provide additional substrate for some saprophytic mycobionts, and consequently, faster growing Ceratorhiza spp. tend to overgrow the seeds. Further, seeds were surface disinfested for 6-8 min because results from a pilot study revealed $3 \mathrm{~min}$ to be relatively ineffective in preventing contamination in seeds of certain populations.

For the germination experiments, seeds of each population were tested against six fungal isolates selected from numerous Platanthera praeclara mycobionts collected from several field sites across Minnesota and Missouri. Seeds from the Bicentennial population were in short supply and could only be tested in the 4 mo stratification test. Of the selected isolates, three represented the fungal genus Ceratorhiza (Blu-86, Ler-94 and Bic-70) and the other three represented Epulorhiza (Hel-166, Blu-61 and Bic-68) (Table 1). Another fungal treatment consisted of coinoculation with two fungal strains $($ Bic-68+70) to test for possible synergistic effects of cohabitation by fungi. Strains selected for cohabitation treatment were those recovered from the youngest strap-leaved seedling because isolates originating from young seedlings were expected to be most successful in supporting germination in vitro. Stratified seeds cultured in the absence of mycobionts served as controls. One Petri dish containing 25-35 orchid seeds inoculated with a fungal strain (or noninoculated control) served as an experimental unit.

Viability, germination and seedling development.-Percent viability was estimated by observing seeds sown for germination tests through a dissecting microscope and recording the number of seeds with round or ovoid hyaline embryos (viable embryos) and dividing by the total number of seeds in a plate. Seed germination, protocorm and seedling development 
were recorded every 15 or $30 \mathrm{~d}$ as: $(0)=$ no germination; (1) = swollen embryo, slightly broken testa and one rhizoid present; $(2)=$ testa completely broken and detached and embryo at least twice the original size with two or more rhizoids present; $(3)=$ top shaped protocorm, appearance of leaf primordium; (4) = elongation of the leaf primordium, further enlargement of protocorm; and $(5)=$ formation of the root initial. The number of germinants in each stage was divided by the number of viable seeds in a plate to obtain germination proportion.

Developing protocorms were exposed to $5 \mathrm{C}$ for 4 mo following the initial incubation for $60 \mathrm{~d}$ or when Stage 5 was observed, whichever came first. Following cold treatment, Stage 5 seedlings were placed under artificial illumination $\left(65-70 \mu \mathrm{E} \mathrm{m}^{-2} \mathrm{~s}^{-1} \mathrm{PAR}\right)$ for $60 \mathrm{~d}$ before returning to 5 C. All other protocorms and seedlings were incubated at ambient temperature in the dark for $60 \mathrm{~d}$ then returned to $5 \mathrm{C}$. Although data were collected at 90 and $120 \mathrm{~d}$ after sowing, almost no further development was observed in the protocorms that had germinated to Stage 2, 3 or 4 previously, and no new germinants were encountered. Therefore, for statistical analyses, only the data collected during the first $60 \mathrm{~d}$ were used. However, included herein is a discussion of the treatments applied to those Stage 5 seedlings that continued development $60 \mathrm{~d}$ after seed sowing.

Experimental design and data analysis. - Germination experiments were conducted at two separate times. For the first experiment, seeds from five populations (Bicentennial, Bluestem, Helton, Hwy 56 and Little Tarkio) were stratified for 4 mo. Seeds from four populations (Bluestem, Helton, Hwy 56 and Little Tarkio) were stratified for 6 mo for the second experiment. Within each stratification experiment, seeds from each population were subjected to eight different isolate treatments.

Five blocks were used in the 4-mo stratification experiment and each block had three determinations (Petri plates) per population/isolate combination. The 6-mo stratification experiment had four blocks in which there were four determinations per treatment combination. All of the population/isolate combinations within a block were run at the same time. Determinations (Petri plates) were averaged before analyses. Thus, each stratification experiment was designed as a randomized complete block design in which the treatments were arranged as a population times isolate factorial.

Two separate ANOVA models were analyzed with percentage germination as the dependent variable. The primary model combined 4- and 6-mo stratification experiments in which populations were common to both. The resultant linear statistic model contained the effects of stratification, block within stratification, population, isolate and all possible interactions with stratification, population and isolate. Stratification was tested using block within stratification as denominator of $\mathrm{F}$. All other effects were tested using the residual error mean square.

A secondary ANOVA model was analyzed only for the 4-mo stratification experiment. This was done mainly to test a population (Bicentennial) that was not included in 6-mo stratification experiment. The linear statistical model contained the effects of block, population, isolate and the interaction of population and isolate.

In both analyses the degrees of freedom for isolate were orthogonally partitioned into one degree of freedom contrasts to compare: (1) the two fungal genera, Ceratorhiza and Epulorhiza; (2) sources of isolates, i.e., root-like organ (protocorm) of a young seedling and roots of mature plants; and (3) germination with or without the isolate Bic-70. Mean differences after $60 \mathrm{~d}$ were determined using Scott-Knott procedure at 5\% based on the arcsin square root transformation. The Scott-Knott procedure was outlined by Scott and Knott (1974) and was further described by Gates and Bilbro (1978); the program used in this study was written by the College of Agriculture, Food and Natural 
Resources Agricultural Experiment Station Statisticians at the University of MissouriColumbia.

A separate analysis was conducted, with seed viability as the dependent variable, to compare viability values for each of the five test populations. Viability was measured for each population, which resulted in a one-way analysis of variance. For this analysis, mean differences were ascertained by using Fisher's LSD at $5 \%$.

All ANOVAs were preformed using PROC GLM procedure in SAS/STAT (1999). Since there were unequal sample sizes, mainly due to contamination, type III sum of squares were used to calculate the $\mathrm{F}$ values.

\section{CHARACTERIZATION OF FUNGAL CULTURES}

Growth rates and colony color.-A $1 \mathrm{~cm}^{3}$ piece of inoculum growing on potato dextrose agar (PDA) was placed in the center of a $9 \mathrm{~cm}$ Petri dish containing cornmeal agar (CMA) or PDA. Three replicates for each isolate and media combination were incubated at $23 \mathrm{C}$. Radial increase of the mycelium was measured at three fronts for each replicate. Data were recorded every $24 \mathrm{~h}$ over $5 \mathrm{~d}$ for faster growing isolates and every $48 \mathrm{~h}$ over $8 \mathrm{~d}$ for mycelia exhibiting slower growth. Underside mycelium color on PDA was visually compared to the standards in the Methuen Handbook of Colour (Kornercup and Wanscher, 1984).

Morphometry of mycelia. - Width and appearance of vegetative hyphae and mycelial appearance on CMA and PDA were examined by light microscopy. Fungal isolates did not produce sclerotia on all media; therefore, appearance of sclerotia and monilioid cell dimensions were measured on OMA, CMA or PDA, whichever substrate induced these entities.

Ultrastructure of the septal pore apparatus. - Small pieces of 7-d-old mycelium growing on PDA were fixed in $2 \%$ paraformaldehyde in cacodylate buffer, $\mathrm{pH} 7.35$, for $2 \mathrm{~h}$ at ambient temperature followed by a secondary fixation in $1 \% \mathrm{OsO}_{4}$ for $2 \mathrm{~h}$ and a tertiary fixation in $1 \%$ aqueous uranyl acetate for $2 \mathrm{~h}$. Samples were then washed in DI water and dehydrated in graded EtOH series and in propylene oxide (PO). After dehydration, specimens were infiltrated with 1:2, 1:1 and 2:1 v/v mixture of Epon Spur : PO for 2, 2 and $8 \mathrm{~h}$, respectively. Samples were subsequently incubated in pure resin twice for $8 \mathrm{~h}$ each and finally, transferred to embedding capsules filled with fresh pure Epon Spur. Capsule and specimens were polymerized at $55 \mathrm{C}$ in an oven for $48 \mathrm{~h}$. Thin sections were cut using a diamond knife on a LKB Ultratome III ultramicrotome, placed on grids and stained in uranyl acetate followed by lead citrate. After washing in DI water, sections were examined in a Hitachi $\mathrm{H}-600$ electron microscope. Detailed characterization results are presented only for the isolate that was most effective in promoting seedling development up to Stage 5 and beyond.

\section{RESUltS AND DiscusSiON}

Seed viability, germination and development.-Flowering plant census in the year 1999 ranged from 12 individuals at Little Tarkio, Missouri to 172 individuals at Bluestem, Minnesota (Table 2). The highest percent viability was obtained in the seed sample from a relatively small Missouri population (36.5\%), whereas only $9.3 \%$ of the seeds collected from the largest study population (Bluestem) contained viable embryos. Populations of varying sizes encounter different selection pressures and yearly variation may exist in patterns of seed viability because of availability and efficiency of pollinators. Our results were based on a sample of seeds collected in a single year; however, similar data collected for a number of years and correlated with demographic data would better elucidate consistent patterns in seed viability of Platanthera praeclara populations.

Stratified seeds from all populations germinated and some germinants progressed to 
TABLE 2.- Site name, location, flowering plant census, number of seeds sown in germination tests and seed viability (presence of round hyaline embryos) of Platanthera praeclara populations sampled in this study

\begin{tabular}{llcccc}
\hline \hline Population & \multicolumn{1}{c}{ Location } & $\begin{array}{c}\text { Census between } \\
1970 \text { and 1999* }\end{array}$ & $\begin{array}{c}1999 \\
\text { Census** }\end{array}$ & $\begin{array}{c}\text { \# of seeds*** } \\
\text { (\# of plants sampled) }\end{array}$ & $\begin{array}{c}\text { Seed } \\
\text { viability (\%) }\end{array}$ \\
\hline Little Tarkio & Holt Co., MO & $5-12$ & 12 & $3767(4)$ & $18.5 \mathrm{c}^{\#}$ \\
Hwy 56 & Mower Co., MN & $0-38$ & 15 & $2792(6)$ & $25.9 \mathrm{~b}$ \\
Bicentennial & Clay Co., MN & $6-33$ & 33 & $2065(4)$ & $21.5 \mathrm{c}$ \\
Helton & Harrison Co., MO & $15-51$ & 51 & $3576(5)$ & $36.5 \mathrm{a}$ \\
Bluestem & Clay Co., MN & $28-172$ & 172 & $3856(15)$ & $9.3 \mathrm{~d}$ \\
\hline
\end{tabular}

* Minimum and maximum number of flowering individuals recorded between 1970 and 1999 [USFWS, 1996; Nancy Sather, Brian Winter, Tim Smith and Dave Ashley (pers. comm.)]

** Number of flowering individuals recorded in 1999 [Nancy Sather, Brian Winter, Tim Smith and Dave Ashley (pers. comm.)]

*** Number of seeds sown for germination tests; viability estimates were based on these numbers

\# Means with the same letter within column are not significantly different as ascertained by Fisher's LSD at $5 \%$

Stage 2 by day 15; however, none developed beyond Stage 2 during this time period (data not presented). Most protocorms showed arrested development and remained at Stage 2 at day 45. Further discussion of treatment effects and mean percentages will be limited to data obtained after $60 \mathrm{~d}$ incubation (Table 3 ). This analysis showed the interaction of fungal isolates $(\mathrm{I})$ with stratification period $(\mathrm{S} \times \mathrm{I})$ and population $(\mathrm{P} \times \mathrm{I})$ to affect in vitro germination of Platanthera praeclara seeds, especially in obtaining higher developmental stages after longer incubation periods (Table 3). As a group, fungi assignable to Ceratorhiza encouraged development to higher stages (Stages 3, 4 and 5) compared to Epulorhiza isolates. Inclusion of the fungal isolate Bic-70 (Ceratorhiza sp.) significantly improved development of protocorms. Mycobionts isolated from strap-leaved seedling were more effective in producing higher-stage protocorms and seedlings when compared to isolates recovered from roots of adult $P$. praeclara plants (Table 3).

Sixty days following seed sowing, most protocorms under all treatments remained at Stage 2. A higher percentage of protocorms in each isolate treatment advanced to Stage 2 when seeds received 6-mo stratification compared to those receiving 4 mo cold pretreatment (Table 4). Although more protocorms developed to Stage 3 under 4 mo stratification treatment in seeds inoculated with Bic-70 and Bic-68+70, fewer Stage 4 protocorms were obtained and none developed further. In comparison, a combination of 6 mo pretreatment and inoculation with Bic- 70 or Bic- $68+70$ resulted in more Stage 4 protocorms; in addition, some germinants advanced to Stage 5 (production and elongation of root initial) when cultured with the same two fungal treatments (Table 4).

In seeds from all four populations, highest developmental stages were obtained only after inoculation with Bic-70 or Bic- $68+70$ (Table 5). Although germination and development up to Stage 2 was observed in uninoculated controls, symbiotically cultured seeds produced more Stage 2 protocorms (Tables 4, 5). Seeds from the Hwy 56 population yielded the highest percentage of Stage 2 protocorms under each isolate treatment showing a high germination potential but development to Stage 3 was limited and only occurred in the presence of Bic-70 or Bic-68+70. During the same period, however, some protocorms from Little Tarkio, Helton and Bluestem populations progressed to Stage 4. Stage 5 seedlings resulted only from seeds collected from Helton and Little Tarkio prairies, when inoculated with Bic-70 alone. 
TABLE 3.-Probabilities of significant $\mathrm{F}$ values, obtained from ANOVA model for the primary analysis of in vitro symbiotic seed germination of Platanthera praeclara in which two stratification experiments (4 mo and $6 \mathrm{mo}$ ) were pooled

\begin{tabular}{|c|c|c|c|c|c|c|}
\hline \multirow[b]{3}{*}{ Source of variation ${ }^{1}$} & \multirow[b]{3}{*}{$\mathrm{df}$} & \multicolumn{5}{|c|}{$\%$ Germination after $60 \mathrm{~d}^{2}$} \\
\hline & & \multicolumn{5}{|c|}{ Stage } \\
\hline & & 1 & 2 & 3 & 4 & 5 \\
\hline Stratification (S) & 1 & $* * * 3$ & $*$ & ns & $*$ & ns \\
\hline Population (P) & 3 & $* * *$ & $* * *$ & $* *$ & $* * *$ & ns \\
\hline $\mathrm{S} \times \mathrm{P}$ & 3 & $* *$ & $* *$ & ns & ns & ns \\
\hline Isolate (I) & 7 & $* * *$ & $* * *$ & $* * *$ & $* * *$ & $*$ \\
\hline C vs. $\mathrm{E}^{4}$ & 1 & ns & ns & $* *$ & $* *$ & $*$ \\
\hline PC vs. $A^{5}$ & 1 & $* * *$ & ns & $* * *$ & $* * *$ & $* *$ \\
\hline With or Without Bic-70 & 1 & $* * *$ & $* * *$ & $* * *$ & $* * *$ & $*$ \\
\hline$S \times I$ & 7 & $* * *$ & ns & $* * *$ & $* * *$ & $*$ \\
\hline$P \times I$ & 21 & $*$ & $*$ & $*$ & $* * *$ & ns \\
\hline $\mathrm{S} \times \mathrm{P} \times \mathrm{I}$ & 21 & ns & ns & ns & ns & ns \\
\hline Block (S) & 7 & & & & & \\
\hline Residual & 184 & & & & & \\
\hline
\end{tabular}

${ }^{1}$ Variables include: Stratification in DI water at 5 C $(2-4 \mathrm{mo}, 6 \mathrm{mo})$; Population (4 - Little Tarkio, Hwy 56, Helton, Bluestem); Isolate (8 - Control, Hel-166, Blu-61, Blu-86, Ler-94, Bic-68, Bic70 , Bic-68+70)

${ }^{2}$ Model response variable $=$ arcsin transformed germination proportion, for Stages $1-5,60 \mathrm{~d}$ after seed sowing

${ }^{3}$ Tabular symbols indicate significance of $\mathrm{F}$ : ***, $\mathrm{P} \leqslant 0.001 ; * *, \mathrm{P} \leqslant 0.01 ; *, \mathrm{P} \leqslant 0.05$; ns, not significant

${ }^{4}$ C, Ceratorhiza; E, Epulorhiza

${ }^{5} \mathrm{PC}$, Isolates recovered from a seedling of P. praeclara; A, Isolates recovered from adult P. praeclara plants

Results from the secondary analysis (Table 6) show that population and isolate interacted to affect germination and development $60 \mathrm{~d}$ after seed sowing. Incubation with or without Bic-70 had a significant effect on all developmental stages. Fungal genus (Ceratorhiza or Epulorhiza) and origin (seedling or adult plant roots) also affected development to higher stages. Germination occurred with all isolate treatments in seeds from each of the five populations, but noninoculated seeds did not develop beyond Stage 1, and progress to Stage 2 and beyond only occurred in the presence of a mycobiont (Table 7).

Total germination was highest in seeds from Hwy 56 followed closely by seeds from Bicentennial. However, few Hwy 56 seeds developed to Stage 3 and none beyond. In comparison, seeds from Bicentennial produced the highest percentage of Stage 3 and Stage 4 (the highest stage achieved after 4-mo stratification) protocorms when inoculated with Bic-70 or Bic- $68+70$. For each population, almost all Stage 3 and all Stage 4 protocorms occurred only in plates inoculated with Bic-70 or Bic-68+70 (Table 7). Given these results, it appears Bicentennial seeds may have the potential to initiate root formation if exposed to 6-mo stratification and inoculated with Bic-70. However, a shortage of Bicentennial seed prevented the implementation of additional tests.

During extended incubation (alternating $5 \mathrm{C}$ and $23 \mathrm{C}$ ) of all protocorms (4- and 6-mo stratification and all populations), no significant change was observed in Stage 3 and 4 protocorms. Protocorms with slower developmental rates did not progress further and 
TABLE 4.-Mean percent germination for each stratification (4 mo, $6 \mathrm{mo}$ ) and isolate combination after $60 \mathrm{~d}$ of symbiotic in vitro culture of cold stratified seeds of Platanthera praeclara

\begin{tabular}{|c|c|c|c|c|c|c|c|}
\hline \multirow[b]{3}{*}{ Stratification period } & \multirow[b]{3}{*}{ Isolate } & \multirow[b]{3}{*}{ \# Viable seeds } & \multicolumn{5}{|c|}{$\%$ Germination after $60 \mathrm{~d}$} \\
\hline & & & \multicolumn{5}{|c|}{ Stage } \\
\hline & & & 1 & 2 & 3 & 4 & 5 \\
\hline \multirow[t]{8}{*}{4 months } & Control & 256 & $6.9 \mathrm{~b} *$ & $0.0 \mathrm{~d}$ & $0.0 \mathrm{~d}$ & $0.0 \mathrm{c}$ & $0.0 \mathrm{~b}$ \\
\hline & Hel-166 & 262 & $5.6 \mathrm{~b}$ & $23.6 \mathrm{~b}$ & $0.0 \mathrm{~d}$ & $0.0 \mathrm{c}$ & $0.0 \mathrm{~b}$ \\
\hline & Blu-61 & 314 & $14.2 \mathrm{a}$ & $18.6 \mathrm{~b}$ & $0.0 \mathrm{~d}$ & $0.0 \mathrm{c}$ & $0.0 \mathrm{~b}$ \\
\hline & Blu-86 & 273 & $18.8 \mathrm{a}$ & $11.2 \mathrm{c}$ & $0.0 \mathrm{~d}$ & $0.0 \mathrm{c}$ & $0.0 \mathrm{~b}$ \\
\hline & Ler-94 & 276 & $8.8 \mathrm{~b}$ & $18.3 \mathrm{~b}$ & $0.0 \mathrm{~d}$ & $0.0 \mathrm{c}$ & $0.0 \mathrm{~b}$ \\
\hline & Bic-68 & 268 & $5.6 \mathrm{~b}$ & $21.7 \mathrm{~b}$ & $0.0 \mathrm{~d}$ & $0.0 \mathrm{c}$ & $0.0 \mathrm{~b}$ \\
\hline & Bic-70 & 271 & $3.2 \mathrm{c}$ & $26.5 \mathrm{a}$ & $3.0 \mathrm{~d}$ & $0.1 \mathrm{c}$ & $0.0 \mathrm{~b}$ \\
\hline & Bic- $68+70$ & 298 & $0.9 \mathrm{c}$ & $22.5 \mathrm{~b}$ & $10.6 \mathrm{a}$ & $0.4 \mathrm{c}$ & $0.0 \mathrm{~b}$ \\
\hline \multirow[t]{8}{*}{6 months } & Control & 294 & $0.6 \mathrm{c}$ & $12.0 \mathrm{c}$ & $0.0 \mathrm{~d}$ & $0.0 \mathrm{c}$ & $0.0 \mathrm{~b}$ \\
\hline & Hel-166 & 300 & $0.0 \mathrm{c}$ & $34.6 \mathrm{a}$ & $0.0 \mathrm{~d}$ & $0.0 \mathrm{c}$ & $0.0 \mathrm{~b}$ \\
\hline & Blu-61 & 297 & $0.5 \mathrm{c}$ & $31.9 \mathrm{a}$ & $0.0 \mathrm{~d}$ & $0.0 \mathrm{c}$ & $0.0 \mathrm{~b}$ \\
\hline & Blu-86 & 296 & $0.3 \mathrm{c}$ & $23.7 \mathrm{~b}$ & $0.0 \mathrm{~d}$ & $0.0 \mathrm{c}$ & $0.0 \mathrm{~b}$ \\
\hline & Ler-94 & 296 & $0.8 \mathrm{c}$ & $34.4 \mathrm{a}$ & $0.0 \mathrm{~d}$ & $0.0 \mathrm{c}$ & $0.0 \mathrm{~b}$ \\
\hline & Bic-68 & 282 & $1.6 \mathrm{c}$ & $24.8 \mathrm{~b}$ & $0.0 \mathrm{~d}$ & $0.0 \mathrm{c}$ & $0.0 \mathrm{~b}$ \\
\hline & Bic-70 & 320 & $0.0 \mathrm{c}$ & $29.5 \mathrm{a}$ & $5.5 \mathrm{~b}$ & $3.1 \mathrm{a}$ & $2.6 \mathrm{a}$ \\
\hline & Bic- $68+70$ & 340 & $0.0 \mathrm{c}$ & $26.9 \mathrm{~b}$ & $3.2 \mathrm{c}$ & $1.7 \mathrm{~b}$ & $1.0 \mathrm{~b}$ \\
\hline
\end{tabular}

* Scott-Knott mean separation was based on arcsin-transformed data and applied to nontransformed means. Means with the same letter within column are not significantly different $(\alpha=0.05)$

appeared to become developmentally arrested, whereas those that had progressed to Stage 5 continued further growth.

Development beyond Stage 5.-During the cold-incubation, Stage 5 seedlings developed minimally; however, once placed under artificial illumination $\left(65-70 \mu \mathrm{E} \mathrm{m}^{-2} \mathrm{~s}^{-1} \mathrm{PAR}\right)$, the first true leaf (strap leaf) initiated green pigmentation and expanded to 1-2 $\mathrm{cm}$ within $30 \mathrm{~d}$ (Figs. 1, 2). After $50 \mathrm{~d}$ of exposure to illumination, the leaf grew to $8 \mathrm{~cm}$ in length, and the seedling produced several lateral roots.

Our symbiotic germination results are especially encouraging because of the typically slow developmental rate in temperate terrestrial orchids; in vitro seedling growth in temperate orchids such as Cypripedium spp. and Platanthera spp. is reported to be slow even in cultures supplemented with artificial nutrient media (Bill Steele and Mark Heck, pers. comm.). Others have also reported slow and erratic patterns in germination and development of terrestrial orchids (e.g., Clements et al., 1986; Currah et al., 1989; Zettler and McInnis, 1992; Rasmussen, 1995; Takahashi et al., 2000). The percentage of leaf-bearing seedlings in this study was similar to or higher than those obtained by symbiotic culture of other Platanthera species. It is common for ca. 0 to $3 \%$ of seeds to develop into leaf-bearing seedlings (e.g., P. obtusata, P. orbiculata, P. hyperborea and P. bifolia, Smreciu and Currah, 1989; P. integrilabia, Zettler, 1992; P. clavellata, Zettler and Hofer, 1998; P. leucophaea, Zettler et al., 2001).

Rarely were new germinants observed during an extended (9 mo) incubation of seeds in this study. However, seeds of terrestrial orchids have been reported to germinate in vitro over a period of up to 12 mo (Stoutamire, 1974; Rasmussen and Rasmussen, 1991). Baskin and Baskin (1998) suggest that delayed germination due to seed polymorphism may be an inherent characteristic of seeds of temperate origin preventing simultaneous germination of the seed bank. In nature, seeds of Platanthera praeclara may germinate during the first spring 
TABLE 5.-Mean percent germination for each population and isolate combination after $60 \mathrm{~d}$ of symbiotic in vitro culture of cold stratified seeds of Platanthera praeclara from four populations. Data were pooled for 4 mo stratification and 6 mo stratification experiments

\begin{tabular}{|c|c|c|c|c|c|c|c|}
\hline \multirow[b]{3}{*}{ Population } & \multirow[b]{3}{*}{ Isolate } & \multirow[b]{3}{*}{ \# Viable seeds } & \multicolumn{5}{|c|}{$\%$ Germination after $60 \mathrm{~d}$} \\
\hline & & & \multicolumn{5}{|c|}{ Stage } \\
\hline & & & 1 & 2 & 3 & 4 & 5 \\
\hline \multirow[t]{8}{*}{ Little Tarkio, MO } & Control & 120 & $0.0 \mathrm{~b}^{*}$ & $0.0 \mathrm{~d}$ & $0.0 \mathrm{c}$ & $0.0 \mathrm{~b}$ & $0.0 \mathrm{~b}$ \\
\hline & Hel-166 & 104 & $2.4 \mathrm{~b}$ & $11.4 \mathrm{c}$ & $1.2 \mathrm{c}$ & $0.0 \mathrm{~b}$ & $0.0 \mathrm{~b}$ \\
\hline & Blu-61 & 130 & $0.6 \mathrm{~b}$ & $3.7 \mathrm{~d}$ & $0.0 \mathrm{c}$ & $0.0 \mathrm{~b}$ & $0.0 \mathrm{~b}$ \\
\hline & Blu-86 & 92 & $0.7 \mathrm{~b}$ & $4.3 \mathrm{~d}$ & $0.0 \mathrm{c}$ & $0.0 \mathrm{~b}$ & $0.0 \mathrm{~b}$ \\
\hline & Ler-94 & 97 & $3.4 \mathrm{~b}$ & $12.7 \mathrm{c}$ & $0.0 \mathrm{c}$ & $0.0 \mathrm{~b}$ & $0.0 \mathrm{~b}$ \\
\hline & Bic-68 & 120 & $2.5 \mathrm{~b}$ & $1.6 \mathrm{~d}$ & $0.0 \mathrm{c}$ & $0.0 \mathrm{~b}$ & $0.0 \mathrm{~b}$ \\
\hline & Bic-70 & 97 & $0.9 \mathrm{~b}$ & $8.1 \mathrm{~d}$ & $1.8 \mathrm{c}$ & $1.2 \mathrm{~b}$ & $0.6 \mathrm{a}$ \\
\hline & Bic- $68+70$ & 108 & $1.7 \mathrm{~b}$ & $0.9 \mathrm{~d}$ & $3.9 \mathrm{~b}$ & $0.0 \mathrm{~b}$ & $0.0 \mathrm{~b}$ \\
\hline \multirow[t]{8}{*}{ Hwy 56, MN } & Control & 134 & $12.1 \mathrm{a}$ & $21.0 \mathrm{c}$ & $0.0 \mathrm{c}$ & $0.0 \mathrm{~b}$ & $0.0 \mathrm{~b}$ \\
\hline & Hel-166 & 191 & $4.1 \mathrm{~b}$ & $61.5 \mathrm{a}$ & $0.0 \mathrm{c}$ & $0.0 \mathrm{~b}$ & $0.0 \mathrm{~b}$ \\
\hline & Blu-61 & 152 & $11.4 \mathrm{a}$ & $57.4 \mathrm{a}$ & $0.0 \mathrm{c}$ & $0.0 \mathrm{~b}$ & $0.0 \mathrm{~b}$ \\
\hline & Blu-86 & 156 & $21.5 \mathrm{a}$ & $38.8 \mathrm{~b}$ & $0.0 \mathrm{c}$ & $0.0 \mathrm{~b}$ & $0.0 \mathrm{~b}$ \\
\hline & Ler-94 & 180 & $5.3 \mathrm{a}$ & $42.8 \mathrm{~b}$ & $0.0 \mathrm{c}$ & $0.0 \mathrm{~b}$ & $0.0 \mathrm{~b}$ \\
\hline & Bic-68 & 157 & $5.7 \mathrm{a}$ & $50.9 \mathrm{a}$ & $0.0 \mathrm{c}$ & $0.0 \mathrm{~b}$ & $0.0 \mathrm{~b}$ \\
\hline & Bic-70 & 198 & $4.0 \mathrm{~b}$ & $65.5 \mathrm{a}$ & $2.0 \mathrm{c}$ & $0.0 \mathrm{~b}$ & $0.0 \mathrm{~b}$ \\
\hline & Bic- $68+70$ & 193 & $0.0 \mathrm{~b}$ & $64.0 \mathrm{a}$ & $3.6 \mathrm{~b}$ & $0.0 \mathrm{~b}$ & $0.0 \mathrm{~b}$ \\
\hline \multirow[t]{8}{*}{ Helton, MO } & Control & 215 & $2.4 \mathrm{~b}$ & $2.0 \mathrm{~d}$ & $0.0 \mathrm{c}$ & $0.0 \mathrm{~b}$ & $0.0 \mathrm{~b}$ \\
\hline & Hel-166 & 178 & $3.6 \mathrm{~b}$ & $20.7 \mathrm{c}$ & $0.8 \mathrm{c}$ & $0.0 \mathrm{~b}$ & $0.0 \mathrm{~b}$ \\
\hline & Blu-61 & 222 & $5.8 \mathrm{a}$ & $25.0 \mathrm{c}$ & $0.0 \mathrm{c}$ & $0.0 \mathrm{~b}$ & $0.0 \mathrm{~b}$ \\
\hline & Blu-86 & 225 & $6.1 \mathrm{a}$ & $10.7 \mathrm{c}$ & $0.0 \mathrm{c}$ & $0.0 \mathrm{~b}$ & $0.0 \mathrm{~b}$ \\
\hline & Ler-94 & 213 & $6.2 \mathrm{a}$ & $21.8 \mathrm{c}$ & $0.0 \mathrm{c}$ & $0.0 \mathrm{~b}$ & $0.0 \mathrm{~b}$ \\
\hline & Bic-68 & 199 & $2.8 \mathrm{~b}$ & $20.2 \mathrm{c}$ & $0.0 \mathrm{c}$ & $0.0 \mathrm{~b}$ & $0.0 \mathrm{~b}$ \\
\hline & Bic-70 & 216 & $0.5 \mathrm{~b}$ & $19.0 \mathrm{c}$ & $11.1 \mathrm{a}$ & $3.0 \mathrm{a}$ & $1.0 \mathrm{a}$ \\
\hline & Bic- $68+70$ & 249 & $0.0 \mathrm{~b}$ & $10.8 \mathrm{c}$ & $10.8 \mathrm{a}$ & $3.9 \mathrm{a}$ & $0.0 \mathrm{~b}$ \\
\hline \multirow[t]{8}{*}{ Bluestem, MN } & Control & 81 & $2.5 \mathrm{~b}$ & $3.5 \mathrm{~d}$ & $0.0 \mathrm{c}$ & $0.0 \mathrm{~b}$ & $0.0 \mathrm{~b}$ \\
\hline & Hel-166 & 89 & $2.2 \mathrm{~b}$ & $24.6 \mathrm{c}$ & $0.0 \mathrm{c}$ & $0.0 \mathrm{~b}$ & $0.0 \mathrm{~b}$ \\
\hline & Blu-61 & 107 & $14.3 \mathrm{a}$ & $16.0 \mathrm{c}$ & $0.0 \mathrm{c}$ & $0.0 \mathrm{~b}$ & $0.0 \mathrm{~b}$ \\
\hline & Blu-86 & 96 & $14.3 \mathrm{a}$ & $14.2 \mathrm{c}$ & $0.0 \mathrm{c}$ & $0.0 \mathrm{~b}$ & $0.0 \mathrm{~b}$ \\
\hline & Ler-94 & 82 & $5.7 \mathrm{a}$ & $27.2 \mathrm{c}$ & $0.0 \mathrm{c}$ & $0.0 \mathrm{~b}$ & $0.0 \mathrm{~b}$ \\
\hline & Bic-68 & 74 & $4.2 \mathrm{~b}$ & $22.8 \mathrm{c}$ & $0.0 \mathrm{c}$ & $0.0 \mathrm{~b}$ & $0.0 \mathrm{~b}$ \\
\hline & Bic-70 & 80 & $1.9 \mathrm{~b}$ & $23.1 \mathrm{c}$ & $1.4 \mathrm{c}$ & $1.5 \mathrm{~b}$ & $0.0 \mathrm{~b}$ \\
\hline & Bic- $68+70$ & 88 & $0.0 \mathrm{~b}$ & $31.2 \mathrm{~b}$ & $9.3 \mathrm{~b}$ & $0.0 \mathrm{~b}$ & $0.0 \mathrm{~b}$ \\
\hline
\end{tabular}

* Scott-Knott mean separation was based on arcsin-transformed data and applied to nontransformed means. Means with the same letter within column are not significantly different $(\alpha=0.05)$

following capsule dehiscence and seed dispersal but further development of the protocorms may only occur after exposure to one or more winters. Platanthera praeclara seeds placed in nylon mesh bags only yielded Stage 2 protocorms following in situ incubation for approximately $20 \mathrm{mo}$ at both Missouri prairies (Sharma, 2002). These observations suggest that germination and development of $P$. praeclara can be improved considerably with in vitro stratification and germination strategies. Other researchers have observed similar trends; for example, Zelmer and Currah (1997) reported in situ development of Spiranthes lacera to be much slower compared to that in vitro. 
TABLE 6.-Probabilities of significant $\mathrm{F}$ values, obtained from ANOVA model for the secondary analysis of in vitro symbiotic culture of Platanthera praeclara seeds from five populations stratified for 4 mo and tested for germination with 8 isolate treatments

\begin{tabular}{|c|c|c|c|c|c|}
\hline \multirow[b]{3}{*}{ Source of variation ${ }^{1}$} & \multirow[b]{3}{*}{$\mathrm{df}$} & \multicolumn{4}{|c|}{$\%$ Germination after $60 \mathrm{~d}^{2}$} \\
\hline & & \multicolumn{4}{|c|}{ Stage } \\
\hline & & 1 & 2 & 3 & 4 \\
\hline Block & 4 & $\mathrm{~ns}^{3}$ & $*$ & ns & ns \\
\hline Population (P) & 4 & $* * *$ & $* * *$ & ns & $* *$ \\
\hline Isolate (I) & 7 & $* * *$ & $* * *$ & $* * *$ & $* *$ \\
\hline C vs. $\mathrm{E}^{4}$ & 1 & ns & ns & $*$ & $*$ \\
\hline PC vs. $A^{5}$ & 1 & $* * *$ & ns & $*$ & $*$ \\
\hline With or Without Bic70 & 1 & $* * *$ & $* * *$ & $* * *$ & $* * *$ \\
\hline$P \times I$ & 28 & $*$ & ns & $*$ & $* * *$ \\
\hline Residual & 128 & & & & \\
\hline
\end{tabular}

${ }^{1}$ Variables include: Population ( 5 - Little Tarkio, Hwy 56, Bicentennial, Helton, Bluestem); Isolate (8 - Control, Hel-166, Blu-61, Blu-86, Ler-94, Bic-68, Bic-70, Bic-68+70)

${ }^{2}$ Model response variable $=$ arcsin transformed germination proportion, for Stages 1-4, $60 \mathrm{~d}$ after seed sowing

${ }^{3}$ Tabular symbols indicate significance of $\mathrm{F}: * * *, \mathrm{P} \leqslant 0.001 ; * *, \mathrm{P} \leqslant 0.01 ; *, \mathrm{P} \leqslant 0.05$; ns, not significant

${ }^{4}$ C, Ceratorhiza; E, Epulorhiza

${ }^{5} \mathrm{PC}$, Isolates recovered from a seedling of $P$. praeclara; A, Isolates recovered from adult $P$. praeclara plants

Although in vitro scarification treatments were not tested in this study, the brief surface disinfestation period may have caused some abrasion of the testa. Longer scarification (up to $60 \mathrm{~min}$ ) may increase germination, defined "production of 1 to 3 rhizoids," as observed by Stoutamire (1996) in Platanthera leucophaea. However, symbiotically cultured, stratified seeds of the same orchid were reported to reach higher developmental stages (3, 4 and 5) (Zettler et al., 2001).

In our pilot study inoculated nonstratified seeds of Platanthera praeclara failed to germinate, whereas some germination was observed in seeds stratified for as little as 2 mo (data not presented). Low germination percentages were obtained when stratified seeds were incubated in the absence of a mycobiont $(6.9 \%$ after 4 mo stratification and $12.6 \%$ after 6 mo stratification) indicating that stratification alone does not optimize in vitro germination and development. The mycobiont can significantly increase in vitro germination. Bic-70 (Ceratorhiza sp.), individually and in combination with Bic-68 (an Epulorhiza sp.), supported development of protocorms to advanced stages (Stage 3 onward) under all stratification and population treatments. Both mycobionts Bic-70 and Bic-68 were derived from a seedling. These results support the hypothesis that isolates originating from $P$. praeclara seedlings would be more successful in supporting in vitro development of the species than isolates from mature plants (Tables 3,6). Results from this study are in agreement with those of other studies where fungi derived from seedlings (Zelmer and Currah, 1997) or protocorms (Zettler, 1994) were effective in in vitro development of advanced stage seedlings of Spiranthes lacera and $P$. integrilabia, respectively. We advocate that conservation projects directed at other temperate orchids include isolates recovered from seedlings and naturally-occurring protocorms.

The fungal isolate Bic-70 was the superior strain for promoting in vitro germination and 
TABLE 7.-Mean percent germination after $60 \mathrm{~d}$ of symbiotic in vitro culture of cold stratified (4 mo) seeds of Platanthera praeclara

\begin{tabular}{|c|c|c|c|c|c|c|}
\hline \multirow[b]{3}{*}{ Population } & \multirow[b]{3}{*}{ Isolate } & \multirow[b]{3}{*}{ \# Viable seeds } & \multicolumn{4}{|c|}{$\%$ Germination after $60 \mathrm{~d}$} \\
\hline & & & \multicolumn{4}{|c|}{ Stage } \\
\hline & & & 1 & 2 & 3 & 4 \\
\hline \multirow[t]{8}{*}{ Little Tarkio, MO } & Control & 73 & $0.0 \mathrm{~b}^{*}$ & $0.0 \mathrm{c}$ & $0.0 \mathrm{c}$ & $0.0 \mathrm{~b}$ \\
\hline & Hel-166 & 68 & $4.3 \mathrm{~b}$ & $17.9 \mathrm{~b}$ & $0.0 \mathrm{c}$ & $0.0 \mathrm{~b}$ \\
\hline & Blu-61 & 80 & $1.1 \mathrm{~b}$ & $1.3 \mathrm{c}$ & $0.0 \mathrm{c}$ & $0.0 \mathrm{~b}$ \\
\hline & Blu-86 & 58 & $1.1 \mathrm{~b}$ & $2.0 \mathrm{c}$ & $0.0 \mathrm{c}$ & $0.0 \mathrm{~b}$ \\
\hline & Ler-94 & 56 & $6.2 \mathrm{~b}$ & $4.2 \mathrm{c}$ & $0.0 \mathrm{c}$ & $0.0 \mathrm{~b}$ \\
\hline & Bic-68 & 75 & $4.5 \mathrm{~b}$ & $1.0 \mathrm{c}$ & $0.0 \mathrm{c}$ & $0.0 \mathrm{~b}$ \\
\hline & Bic-70 & 54 & $1.7 \mathrm{~b}$ & $10.2 \mathrm{c}$ & $0.0 \mathrm{c}$ & $0.0 \mathrm{~b}$ \\
\hline & Bic- $-68+70$ & 55 & $3.1 \mathrm{~b}$ & $1.7 \mathrm{c}$ & $6.1 \mathrm{~b}$ & $0.0 \mathrm{~b}$ \\
\hline \multirow[t]{8}{*}{ Hwy 56, MN } & Control & 38 & $26.7 \mathrm{a}$ & $0.0 \mathrm{c}$ & $0.0 \mathrm{c}$ & $0.0 \mathrm{~b}$ \\
\hline & Hel-166 & 61 & $8.3 \mathrm{~b}$ & $44.1 \mathrm{a}$ & $0.0 \mathrm{c}$ & $0.0 \mathrm{~b}$ \\
\hline & Blu-61 & 69 & $22.9 \mathrm{a}$ & $46.4 \mathrm{a}$ & $0.0 \mathrm{c}$ & $0.0 \mathrm{~b}$ \\
\hline & Blu-86 & 47 & $43.0 \mathrm{a}$ & $21.8 \mathrm{~b}$ & $0.0 \mathrm{c}$ & $0.0 \mathrm{~b}$ \\
\hline & Ler-94 & 65 & $9.8 \mathrm{~b}$ & $25.8 \mathrm{~b}$ & $0.0 \mathrm{c}$ & $0.0 \mathrm{~b}$ \\
\hline & Bic-68 & 46 & $9.5 \mathrm{~b}$ & $44.2 \mathrm{a}$ & $0.0 \mathrm{c}$ & $0.0 \mathrm{~b}$ \\
\hline & Bic-70 & 47 & $7.9 \mathrm{~b}$ & $55.0 \mathrm{a}$ & $0.0 \mathrm{c}$ & $0.0 \mathrm{~b}$ \\
\hline & Bic- $68+70$ & 62 & $0.0 \mathrm{~b}$ & $57.0 \mathrm{a}$ & $5.7 \mathrm{~b}$ & $0.0 \mathrm{~b}$ \\
\hline \multirow[t]{8}{*}{ Bicentennial, MN } & Control & 41 & $34.4 \mathrm{a}$ & $0.0 \mathrm{c}$ & $0.0 \mathrm{c}$ & $0.0 \mathrm{~b}$ \\
\hline & Hel-166 & 64 & $4.9 \mathrm{~b}$ & $53.3 \mathrm{a}$ & $0.0 \mathrm{c}$ & $0.0 \mathrm{~b}$ \\
\hline & Blu-61 & 64 & $16.0 \mathrm{a}$ & $24.6 \mathrm{~b}$ & $0.0 \mathrm{c}$ & $0.0 \mathrm{~b}$ \\
\hline & Blu-86 & 61 & $22.9 \mathrm{a}$ & $22.4 \mathrm{~b}$ & $0.0 \mathrm{c}$ & $0.0 \mathrm{~b}$ \\
\hline & Ler-94 & 72 & $15.0 \mathrm{a}$ & $43.7 \mathrm{a}$ & $2.4 \mathrm{c}$ & $0.0 \mathrm{~b}$ \\
\hline & Bic-68 & 56 & $9.6 \mathrm{~b}$ & $23.6 \mathrm{~b}$ & $0.0 \mathrm{c}$ & $0.0 \mathrm{~b}$ \\
\hline & Bic-70 & 46 & $0.0 \mathrm{~b}$ & $47.0 \mathrm{a}$ & $12.9 \mathrm{a}$ & $4.0 \mathrm{~b}$ \\
\hline & Bic- $-68+70$ & 51 & $0.0 \mathrm{~b}$ & $37.3 \mathrm{~b}$ & $16.3 \mathrm{a}$ & $17.3 \mathrm{a}$ \\
\hline \multirow[t]{8}{*}{ Helton, MO } & Control & 130 & $3.5 \mathrm{~b}$ & $0.0 \mathrm{c}$ & $0.0 \mathrm{c}$ & $0.0 \mathrm{~b}$ \\
\hline & Hel-166 & 109 & $6.5 \mathrm{~b}$ & $15.5 \mathrm{~b}$ & $0.0 \mathrm{c}$ & $0.0 \mathrm{~b}$ \\
\hline & Blu-61 & 132 & $8.7 \mathrm{~b}$ & $26.4 \mathrm{~b}$ & $0.0 \mathrm{c}$ & $0.0 \mathrm{~b}$ \\
\hline & Blu-86 & 133 & $10.2 \mathrm{a}$ & $8.7 \mathrm{c}$ & $0.0 \mathrm{c}$ & $0.0 \mathrm{~b}$ \\
\hline & Ler-94 & 127 & $9.3 \mathrm{~b}$ & $22.8 \mathrm{~b}$ & $0.0 \mathrm{c}$ & $0.0 \mathrm{~b}$ \\
\hline & Bic-68 & 123 & $5.1 \mathrm{~b}$ & $19.3 \mathrm{~b}$ & $0.0 \mathrm{c}$ & $0.0 \mathrm{~b}$ \\
\hline & Bic-70 & 147 & $0.9 \mathrm{~b}$ & $15.9 \mathrm{~b}$ & $11.4 \mathrm{~b}$ & $0.4 \mathrm{~b}$ \\
\hline & Bic $-68+70$ & 148 & $0.0 \mathrm{~b}$ & $12.5 \mathrm{c}$ & $13.7 \mathrm{a}$ & $1.5 \mathrm{~b}$ \\
\hline \multirow[t]{8}{*}{ Bluestem, MN } & Control & 15 & $5.0 \mathrm{~b}$ & $0.0 \mathrm{c}$ & $0.0 \mathrm{c}$ & $0.0 \mathrm{~b}$ \\
\hline & Hel-166 & 24 & $4.0 \mathrm{~b}$ & $20.9 \mathrm{~b}$ & $0.0 \mathrm{c}$ & $0.0 \mathrm{~b}$ \\
\hline & Blu-61 & 33 & $28.6 \mathrm{a}$ & $2.8 \mathrm{c}$ & $0.0 \mathrm{c}$ & $0.0 \mathrm{~b}$ \\
\hline & Blu-86 & 35 & $25.6 \mathrm{a}$ & $14.3 \mathrm{c}$ & $0.0 \mathrm{c}$ & $0.0 \mathrm{~b}$ \\
\hline & Ler-94 & 28 & $10.2 \mathrm{a}$ & $22.0 \mathrm{~b}$ & $0.0 \mathrm{c}$ & $0.0 \mathrm{~b}$ \\
\hline & Bic- 68 & 24 & $4.0 \mathrm{~b}$ & $26.7 \mathrm{~b}$ & $0.0 \mathrm{c}$ & $0.0 \mathrm{~b}$ \\
\hline & Bic-70 & 23 & $3.3 \mathrm{~b}$ & $30.7 \mathrm{~b}$ & $0.0 \mathrm{c}$ & $0.0 \mathrm{~b}$ \\
\hline & Bic $-68+70$ & 33 & $0.0 \mathrm{~b}$ & $32.7 \mathrm{~b}$ & $14.9 \mathrm{a}$ & $0.0 \mathrm{~b}$ \\
\hline
\end{tabular}

* Scott-Knott mean separation was based on arcsin-transformed data and applied to nontransformed means. Means with the same letter within column are not significantly different $(\alpha=0.05)$ 

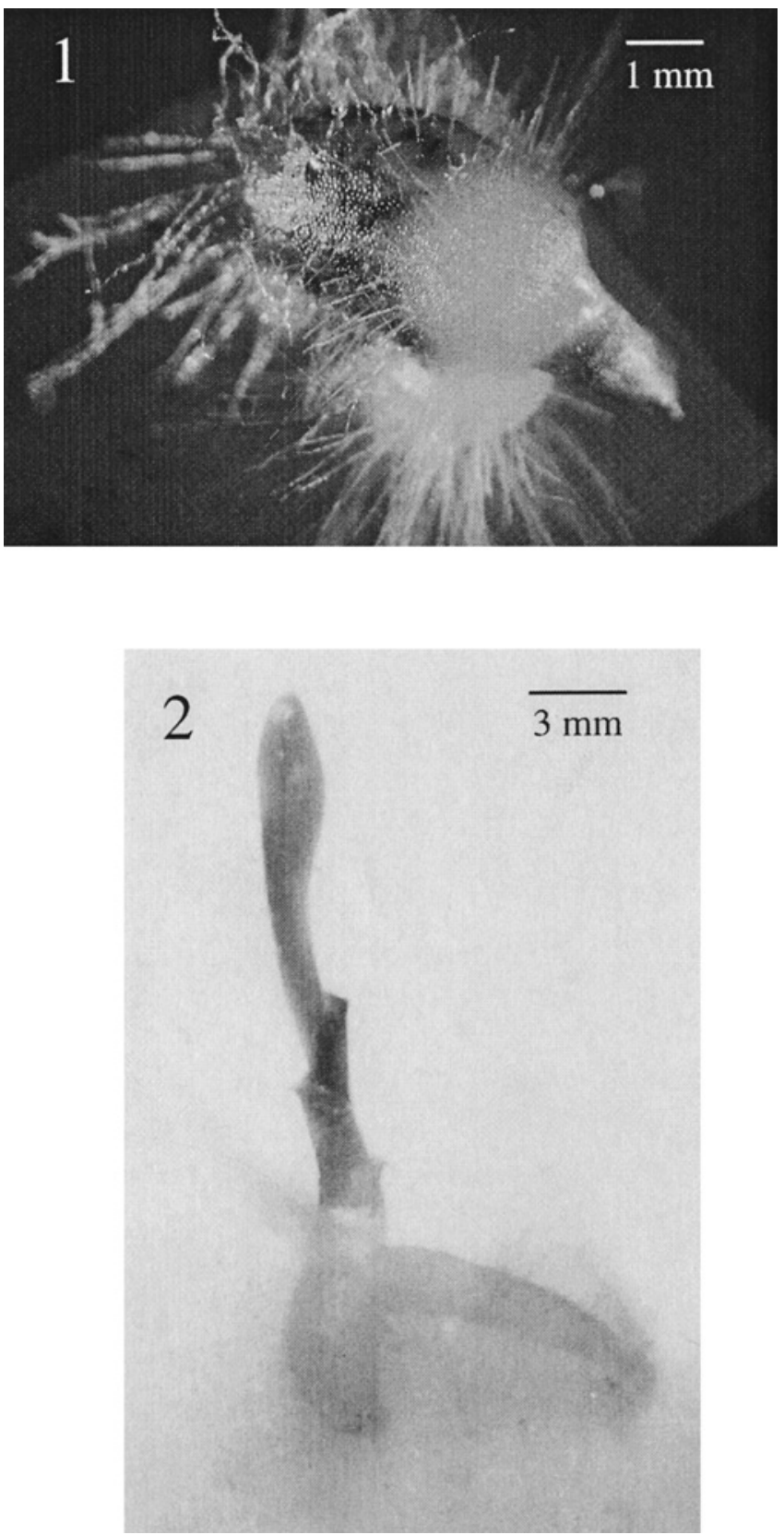

Figs. 1-2.- In vitro development under illumination of Platanthera praeclara seedlings cultured with the Ceratorhiza isolate Bic-70 (UAMH 9847) on modified oatmeal agar. 1. Shoot tip turned green within $20 \mathrm{~d}$ of exposure to light. 2. Expansion of the shoot and lateral root occurred rapidly within $30 \mathrm{~d}$ under the light 
development of Platanthera praeclara seeds up to Stage 5 and beyond. The inability of Bic-68 alone to promote development beyond Stage 2 in any population after 4 - or 6-mo stratification suggests that Bic-70 is likely responsible for the efficacy of cohabitation treatment. In other studies, protocorms of $P$. bifolia, . hyperborea and P. leucophaea, all north temperate species, developed to advanced stages in association with Ceratorhiza spp. (Smreciu and Currah, 1989; Zettler et al., 2001), whereas Epulorhiza spp. supported advanced growth of protocorms of southern orchids $P$. integrilabia, $P$. clavellata and $P$. integra (Zettler and McInnis, 1992; Zettler and Hofer, 1998; Zettler et al., 2000). It is possible that the genus Ceratorhiza may associate preferentially with north temperate Platanthera spp., whereas Epulorhiza strains are the more suitable mycobionts for the southern orchids of this genus.

Mycobionts. - Of the six fungal isolates tested in this study, only Bic-70, derived from a Platanthera praeclara seedling, promoted development to the leaf-bearing stage. This isolate was ascribed to the genus Ceratorhiza based on culture growth rate, colony color, morphometry of mycelia and the ultrastructure of the septal pore apparatus. Detailed description of morphometric and ultrastructure characteristics of the other isolates are presented elsewhere (Sharma, 2002). The colony had loose margins and grew rapidly $(0.24$

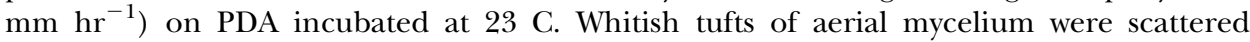
throughout the upper surface initially and eventually covered the entire surface (Fig. 3). As observed from the underside, the mycelium was yellowish tan in color (4B6, Kornerup and Wanscher, 1984) and lacked concentric zonation. Vegetative hyphae were thin walled and hyaline, averaging in width from $5.6 \mu \mathrm{m}$ on CMA to $5.7 \mu \mathrm{m}$ on PDA. Pale yellowish-brown, granular sclerotia formed readily on PDA, OMA and CMA, often first appearing near the site of inoculation. Monilioid cells within sclerotia were borne in loose branched chains and contained an isthmus connecting two adjacent cells. Average dimensions of elliptical thickwalled monilioid cells on CMA were $17.9 \mu \mathrm{m} \times 30.4 \mu \mathrm{m}$ (Fig. 4). When observed with a transmission electron microscope, isolate Bic-70 contained perforate parenthosomes (Fig. 5), a key feature that separates the genus Ceratorhiza from Epulorhiza (Moore, 1987).

Zelmer and Currah (1995) isolated and described Ceratorhiza pernacatena, which was represented by eight isolates recovered from Platanthera praeclara roots collected in Canada. In another study, Zelmer et al. (1996) isolated strains of Epulorhiza and Ceratorhiza (including C. pernacatena) from roots of adult $P$. praeclara, but field-incubated seeds only yielded an Epulorhiza isolate (not identified to the species level). In this study, both Ceratorhiza and Epulorhiza isolates were recovered from a nonphotosynthetic root-like organ of a seedling and from roots of adult plants. These two genera along with the third most common genus of orchidaceous fungi Moniliopsis are routinely isolated from North American orchids (Currah et al., 1987; Currah et al., 1989; Currah and Zelmer, 1992; Zettler et al., in press.). Zettler et al. (2001) reported C. goodyera-repentis from P. leucophaea, the sister species of $P$. praeclara, and speculated that some other isolates recovered from $P$. leucophaea may be C. pernacatena. A comparison of Bic-70 with $C$. pernacatena suggests they might be the same species, however, vegetative characteristics of fungal mycelia are not the most reliable features for identifying fungi to species.

Recovery of Ceratorhiza isolates from Minnesota populations and Epulorhiza from both Minnesota and Missouri populations suggests that these two genera may constitute primary mycobionts of Platanthera praeclara. However, adult plants or field-incubated seeds in Missouri are yet to yield an isolate assignable to Ceratorhiza, implying that orchid fungi may be distributed differently in different regions (Sharma, 2002). Interestingly, in this study, only seeds from Missouri populations developed beyond Stage 5 when assisted by a Ceratorhiza sp. (Bic-70, UAMH 9847).

Cold stratification for 6 mo accompanied by inoculation with a Ceratorhiza isolate derived 

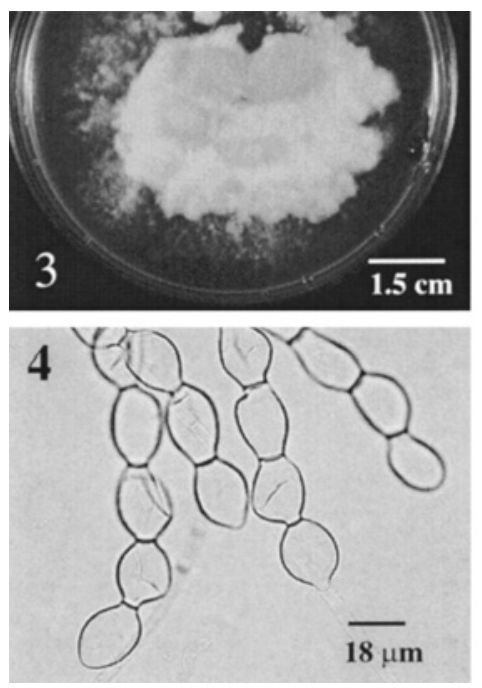

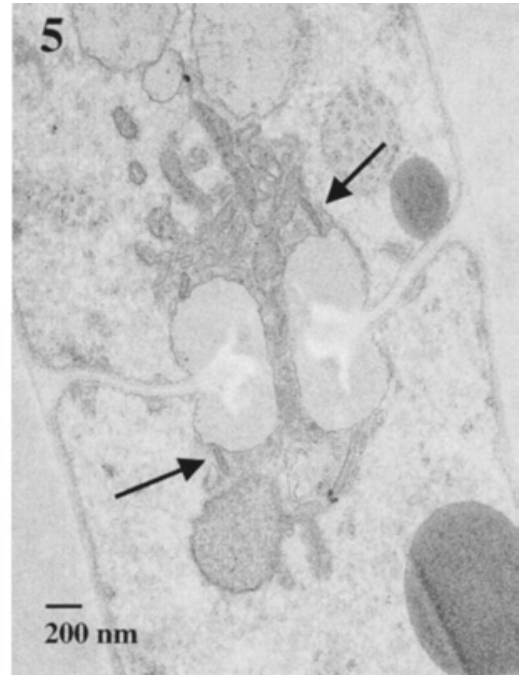

FIGs. 3-5.-Ceratorhiza sp., Bic-70 (UAMH 9847), isolated from the nonphotosynthetic root-like organ of a seedling of Platanthera praeclara. 3. Appearance of Bic-70 on PDA after $20 \mathrm{~d}$ at 23 C. 4. Monilioid cells of Bic-70 on CMA after $60 \mathrm{~d}$ at 23 C. 5. Ultrastructure of the septal pore apparatus revealing perforated parenthosomes (shown by arrows) present on either side of the dolipore

from root-like organ of a seedling yielded advanced stage protocorms and some leafbearing Platanthera praeclara seedlings with mycotrophic ability. Advanced stage seedlings were obtained from seeds collected from smaller as apposed to larger populations, which were expected to yield seeds with higher viability and hence, higher numbers of leafbearing seedlings. Our results underscore the importance of conservation of smaller populations of rare terrestrial orchids, which may produce seeds with higher viability despite lower genetic diversity present within them (Sharma, 2002). Consequently, seed collections for artificial seed banks should contain seeds from populations of different sizes, including relatively small ones.

Acknowledgments.-We sincerely thank the Minnesota Department of Natural Resources (Special Permit Nos. 9416 and 1999-13R), The Nature Conservancy of Minnesota and the Missouri Department of Conservation for allowing access to sites. Special gratitude is extended to Nancy Sather (MNDNR) and Brian Winter (TNC) for assisting with seed capsule collection. Thanks are also extended to the USDA Forest Service and Horticulture and Agroforestry Research Center for the use of facilities; Randy Tindall (University of Missouri-Columbia) for supervising the electron microscopy work; and Scott Stewart (Illinois College) for help with fungal isolation. This research was supported by grants from the Minnesota Department of Natural Resources and the Prairie Forks Conservation Area Trust, Missouri.

\section{Literature Cited}

Anderson, A. B. 1991. Symbiotic and asymbiotic germination and growth of Spiranthes magnicamporum (Orchidaceae). Lindleyana, 6:183-186.

1996. The reintroduction of Platanthera ciliaris in Canada, p. 73-76. In: C. Allen (ed.). Proceedings of the North American native terrestrial orchid-propagation and production conference. National Arboretum, Washington, D.C.

Baskin, C. C. AND J. M. Baskin. 1998. Germination ecology of plants with specialized life cycles and/or 
habitats, p. 482-485. In: Seeds: ecology, biogeography and evolution of dormancy and germination. Academic Press, San Diego, California.

Bowles, M. L., K. A. Jacobs, L. W. Zettler and T. W. Delaney. 2002. Crossing effects on seed viability and experimental germination of the federal threatened Platanthera leucophaea (Orchidaceae). Rhodora, 104:14-30.

Catling, P. M. and V. R. Catling. 1991. A synopsis of breeding systems and pollination in North American orchids. Lindleyana, 6:187-210.

Clements, M. A., H. Muir and P. J. CRibb. 1986. A preliminary report on the symbiotic germination of European terrestrial orchids. Kew Bull., 41:437-445.

CokE, J. L. 1990. Aseptic germination and growth of some terrestrial orchids, p. 90-91. In: C. E. Sawyers (ed.). Proceedings of the North American native terrestrial orchid-propagation and production conference. Brandywine Conservancy, Chadds Ford, Pennsylvania.

CurRah, R. S. AND C. D. ZeLmer. 1992. A key and notes for the genera of fungi mycorrhizal with orchids and a new species in the genus Epulorhiza. Rep. Tottori Mycol. Inst., 30:43-59.

, L. Sigler and S. Hambleton. 1987. New records and new taxa of fungi from the mycorrhizae of terrestrial orchids of Alberta. Can. J. Bot., 65:2473-2482.

E. A. Smreciu and S. Hambleton. 1989. Mycorrhizae and mycorrhizal fungi of boreal species of Platanthera and Coleoglossum (Orchidaceae). Can. J. Bot., 68:1171-1181.

Cuthrell, D. L. ANd D. A. Rider. 1993. Insects associated with the western prairie fringed orchid, Platanthera praeclara Sheviak and Bowles, in the Sheyenne National Grassland. Report to North Dakota parks and recreation board, Bismarck, North Dakota. 42 p.

Dixon, K. 1987. Raising terrestrial orchids from seed, p. 47-100. In: W. K. Harris (ed.). Modern orchid growing for pleasure and profit. Orchid Club of South Australia, Inc., Adelaide, South Australia.

Gates, C. E. AND J. D. Bilbro. 1978. Illustration of a cluster analysis method for mean separation. Agron. J., 70:462-465.

Godt, M. J. And J. L. Hamrick. 2001. Genetic diversity in rare southeastern plants. Nat. Areas J., 21:61-70.

KorneruP, A. AND J. H. WANSCher. 1984. Methuen handbook of colour, 3rd ed. Hastings House, New York. $252 \mathrm{p}$.

Moore, R. T. 1987. The genera of Rhizoctonia-like fungi: Ascorhizoctonia, Ceratorhiza gen. nov., Epulorhiza gen. nov., Moniliopsis and Rhizoctonia. Mycotaxon, 29:91-99.

Pleasants, J. M. And S. Moe. 1993. Floral display size and pollination of the western prairie fringed orchid, Platanthera praeclara (Orchidaceae). Lindleyana, 8:32-38.

Rasmussen, H. N. 1995. Terrestrial orchids: from seed to mycotrophic plant. Cambridge University Press, Cambridge, United Kingdom. 444 p.

AND F. N. RASmussen. 1991. Climatic and seasonal regulation of seed plant establishment in Dactylorhiza majalis inferred from symbiotic experiments in vitro. Lindleyana, 6:221-227.

SAS. 1999. Version 8. SAS Institute Inc., Cary, North Carolina.

SCOTt, A. J. AND M. KNOTt. 1974. A cluster analysis method for grouping means in the analysis of variance. Biometrics, 30:507-512.

SHARMA, J. 2002. Mycobionts, germination, and conservation genetics of federally threatened Platanthera praeclara (Orchidaceae). Ph.D. Dissertation, University of Missouri-Columbia. 145 p.

SheviaK, C. J. ANd M. L. Bowles. 1986. The prairie fringed orchid: a pollinator-isolated species pair. Rhodora, 88:267-290.

Smith, S. E. ANd D. J. ReAd. 1997. Orchid mycorrhizas, p. 349-375. In: Mycorrhizal symbiosis, 2nd ed. Academic Press, California.

Smreciu, E. A. and R. S. CurRah. 1989. Symbiotic germination of seeds of terrestrial orchids of North America and Europe. Lindleyana, 1:6-15.

Stoutamire, W. P. 1974. Terrestrial orchid seedlings, p. 101-128. In: C. L. Withner (ed.). The orchids: scientific studies. Wiley Interscience, New York.

1996. Seeds and seedlings of Platanthera leucophaea (Orchidaceae), p. 55-61. In: C. Allen (ed.). Proceedings of the North American terrestrial orchid-propagation and production conference. National Arboretum, Washington, D.C. 
Summers, B. 1996. Platanthera praeclara Sheviak \& Bowles, p. 42-44. In: J. McKee (ed.). Missouri orchids. Missouri Department of Conservation, Natural History Series, No. 1.

Takahashi, K., I. Ogiwara And N. Hakoda. 2000. Seed germination of Habenaria (pecteilis) radiata (Orchidaceae: Orchideae) in vitro. Lindleyana, 15:59-63.

U.S. Fish, ANd Wildlife Service. 1996. Platanthera praeclara (western prairie fringed orchid) recovery plan. U.S. Fish and Wildlife Service, Ft. Snelling, Minnesota. 101 p.

Zelmer, C. D. ANd R. S. Currah. 1995. Ceratorhiza pernacatena and Epulorhiza calendulina spp. nov.: mycorrhizal fungi of terrestrial orchids. Can. J. Bot., 73:1981-1985. AND R. S. CURRAH. 1997. Symbiotic germination of Spiranthes lacera (Orchidaceae) with a naturally occurring endophyte. Lindleyana, 12:142-148.

- L. Cuthbertson and R. S. CurRah. 1996. Fungi associated with terrestrial orchid mycorrhizas, seeds and protocorms. Mycoscience, 37:439-448.

Zettler, L. W. 1994. Symbiotic seed germination of Platanthera integrilabia (Correll) Luer, an endangered terrestrial orchid. Ph.D. Dissertation, Clemson University, South Carolina. 136 p. AND C. J. Hofer. 1998. Propagation of the little club-spur orchid (Platanthera clavellata) by symbiotic seed germination, and its ecological implications. Env. Exper. Bot., 39:189-195.

AND T. M. MCInNIS, JR. 1992. Propagation of Platanthera integrilabia (Correll) Luer, an endangered terrestrial orchid, through symbiotic seed germination. Lindleyana, 7:154-161.

- J. A. Sunley and T. W. Delaney. 2000. Symbiotic seed germination of an orchid in decline (Platanthera integra) from the green swamp, North Carolina. Castanea, 65(3):207-212.

- J. Sharma and F. N. Rasmussen. Mycorrhizal Diversity, chapter 11. In: K. Dixon, P. Cribb, S. Kell and R. Barrett (eds.). Orchid conservation. Natural History Publications, Borneo. In Press.

— S. L. Stewart, M. L. Bowles And K. A. JaCobs. 2001. Mycorrhizal fungi and cold-assisted symbiotic germination of Federally threatened eastern prairie fringed orchid, Platanthera leucophaea (Nuttall) Lindley. Am. Midl. Nat., 145:168-175. 